\title{
COMPARATIVE ANALYSIS OF MOTOR COORDINATION ABILITIES OF 9-10-YEAR OLD BOYS ON THE BASIS OF REGIONAL (DEMOGRAPHYC) BENCHMARK CONTEXT
}

\author{
Nikolina Tankoucheva
}

Sofia University „St. Kliment Ohridski”, Bulgaria

\begin{abstract}
Changes in socio-economic life are related to new challenges affecting the growing children as well. Reduced motor activity as a consequence of the ubiquitous presence of new technologies, urbanization and social changes, increasing of schooling activity and others, lead to degradation of the physical health, changes in the physical development and fitness of the younger generation.

The purpose of the study is to establish whether there is a difference in the manifestation of motor coordination abilities of 9-10-year-old boys from different regions of Bulgaria classified by population.

Backwards ball throw test, Low jump test and Orientation shuttle run test were used for measurement of the motor coordination abilities of 9-10-year-old-boys.

The demographic factor was determined forming 5 groups depending on the population.

The results provide clear evidence that there are statistically significant differences in manifestation of the motor coordination abilities of 9-10 years-old boys depending on the number of town population.

The most significant practical difference was observed for Orientation shuttle run test or for kinesthetic ability of the low limbs.

Multiple comparisons showed that for the first test - Backwards ball throw test there were not statistical differences between small cities and Sofia city. Probably the pupils from the small cities are as talented to perform the coordination exercises as those in Sofia city. For the second test - Low jump test results showed statistically significant differences for almost all compared pairs. The same conclusion is valid also for Orientation shuttle run test. This means that the number of the population can be a differentiating factor for the manifestation of various motor skills, including motor coordination abilities.
\end{abstract}

Key words: motor coordination abilities, 9-10 years old boys, comparative analysis, demographic principle

\section{INTRODUCTION}

The demographic problem is seen to be one of the main social problems of contemporary Bulgarian society. Population theories are an important part of today's "demography" science that seeks the link between demographic dynamics and economic development (Cholakov, 2012; Sugareva, 2017).
Changes in socio-economic life are related to new challenges affecting the growing children as well. Reduced motor activity as a consequence of the global presence of new technologies, urbanization and social changes, increasing of schooling activity and others, lead to degradation of the physical health, changes in the physical development and fit- 
ness of the younger generation.

The data from the studied literature on the problem show that there is a lag in the development of the physical abilities of adolescents (Boeva, 2012; Bernstein, 1991; Lyah, 2003; Hirtz, 1985; Raczek et al. 2003 etc.). Physical capacity as a complex indicator of the overall functional state of people and their motor skills is closely related to the degree of development and manifestation of the basic physical (motor) abilities. For many pupils there is not any harmony between the development of their physical qualities and their motor skills (Momchilova, 2002).

The development of physical capacity and motoric has a direct relationship with the development of motor coordination (MC). (Dimitrova, 1975; Momchilova, 1996, 2002; Ignatov, 2017). According to Rusev (1995), Grosser et al. (2004), Lyah (2006), Chelishev (2012) etc., they can be described as the ability of human beings to solve the motor tasks in the event of complex and unexpected situations in the most perfect, quick, convenient, economical, precise and intelligent way.

At the elementary school age "foundation is laid" to develop these abilities, as well as to acquire knowledge, skills and habits for coordination exercises (Hirtz, 1985; Momchilova, 1996; Hirtz et al. 2000; Hirtz, Starosta, 2002; Lyah, 2006). Zamashkin and Tolstova (2013) call this age period - "golden age" - referring to the speed of development of the motor coordination abilities.

There are five basic motor coordination abilities to learn in physical education classes (Hirtz, 1986; Rusev, 2005): ability for spatial orientation, kinesthetic differentiation ability, balance ability, ability of reaction; rhythmic ability.

For the 2018/19 school year the educational objectives of the PE curriculum for the third graders in Bulgaria required that pupils master the compulsory curriculum of athletics, gymnastics and sports games. Elective areas of learning content required the mastery of at least one sport or a motor-cognitive activity (https://www.mon.bg/bg/1689). Of the recommended percentage distribution of the mandatory hours for the year - 80 hours, $16 \%$ are dedicated to the development of motor abilities. The choice of additional sports disciplines is made by the school management, according to the conditions, traditions, qualification of the pedagogues and the interests of the pupils.

Many surveys have been carried out on the study of the manifestations of the motor coordination abilities for school physical education and in particular among children in primary school age (Momchilova, 1996; Fedyakina, 1998; Magomedov, 1999; Kohoutek, 2005; Lyah, 2006; Pisarenkova, 2010; Grozdeva, 2010; Turchak, 2014; Zlatev et al. 2016)

Coordinating performance is typically measured by sports motor tests that are standardized driving tasks and meet three classic quality criteria: objectivity, reliability and validity.

In reality, simple control exercises can give an idea of how well children have developed in primary school and what practical abilities they have (Roth, 2014).

The aim of the study was to establish whether there is a difference in the manifestation of motor coordination abilities of 9-10-year-old boys from different regions of Bulgaria classified by population.

The purpose solution will allow to assess the actual condition of these abilities for pupils of the third grade for the school year 2018/19 according to the emerging demographic changes in Bulgaria reflecting education as a social phenomenon (including physical education and sport) and, respectively, necessary to update and develop criteria for motor coordination abilities control that will positively influence the physical development of the growing generation. 


\section{METHOD AND MATERIALS}

Object of the study - quantitative and qualitative characteristics of the upper and lower limb kinesthetic discrimination ability and lower limb response orientation ability.

\section{Participants}

The study was carried out in a total of 13 Bulgarian schools. Of them - 7 secondary schools (SS) - with education from 1 st to 12 th grade and 6 Primary schools (PS) - from 1st to 4 th grade. The 564 boys from different cities in the country, aged 9-10 years, of the third grade were tested, divided into five groups according to the population (http://www.nsi. bg/bg/content/2981/):

$\checkmark$ "Very large cities "- with a population of over than 200, 000 inhabitants - Sofia (Code 1);

$\checkmark$ "Big cities" - with a population of 100,000 to 200, 000 inhabitants - Plovdiv and Bourgas (Code 2);

$\checkmark$ "Medium Cities" - with a population of 30, 000 to 100, 000 inhabitants - Veliko Tarnovo and Targovishte (Code 3);

$\checkmark$ "Small cities" - with a population of 10,000 to 30, 000 inhabitants - Smolyan, Svilengrad and Radomir (Code 4);

$\checkmark$ "Very small cities" - with a population of less than 10, 000 - Kubrat and Smilyan (Code 5).

The research was conducted in OctoberNovember 2018.

\section{Measurements}

From the analysis of the studied literature, three tests for structuring the testing battery were selected under the field conditions (field evaluation). There is no common practice to perform a pre-test to minimize the learning effect during the research. The test battery was confirmed from Hirtz et al. (1985) by administering a large and representative sample of school-aged children (Table 1). According to Di Cagno et al. (2013) this battery has high test-retest reliability (Infraclass correlation coefficient (ICC) range 0.80-0.85 - authors' unpublished data). The second test was adapted - "with a rebound from the floor" due to the lack of equipment (plinth) in some schools.

Table 1. Hirtz's battery test description (Hirtz et. al., 1985)

Test

№

Name and description

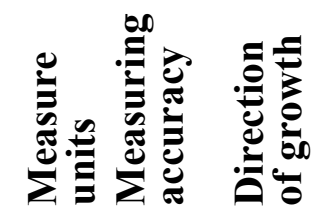

$1 \quad$ Backwards ball throw test (BBT) (Figure 1)

Participants performed a one-hand overhead throw backwards with a tennis ball. They were instructed to center a ground target located $250 \mathrm{~cm}$ behind the performer. The target had a $20 \mathrm{~cm}$ diameter. After a training throw, participants performed five consecutive trials. Five points were assigned for each centered target. Scores of $4,3,2,1$ and 0 were assigned with increasing distance of the contact point of the ball from the target and the mean score was computed.

2 Low jump test (LJ) (Figure 2)

Participants jumped with the legs together from the floor (adapted) to a ground marking at a set distance $(1 \mathrm{~m})$. They were instructed to land with their heels on the marking. The test was performed twice and the distance of each heel from the marking was measured in $\mathrm{cm} \quad 0.5$ centimeters for each trial. The values of the distance of the two heels are averaged. The better result was taken into account. 
3 Orientation shuttle run test (OSR) (Figure 3)

The participant was instructed to run three times, as quickly as possible, from a start marker toward one of five numbered goal markers located behind him. The goal markers were $3 \mathrm{~m}$ apart from him and $1.5 \mathrm{~m}$ apart from another on a hypothetical circumference arc. The sequence of goal markings to be reached was not known previously. The next marking number was announced when the participant returned to the start ball and touched it for the next run to begin without pausing. After demonstration by an experimenter, participants performed the test.

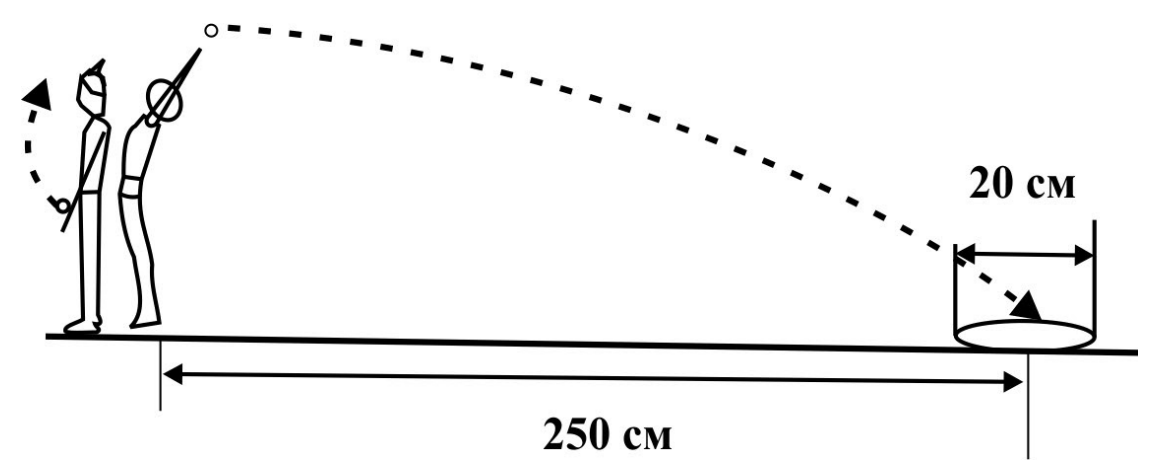

Figure 1. Backwards ball throw test (BBT)

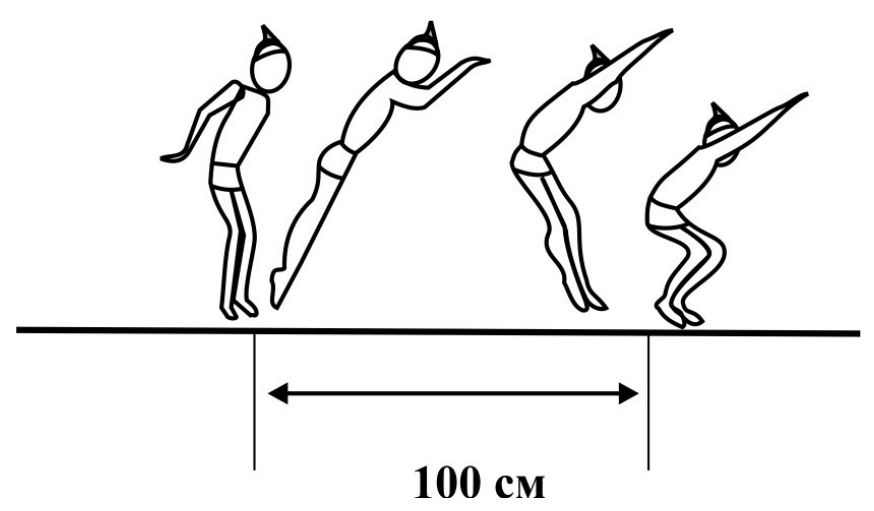

Figure 2. Low jump test (LJ)

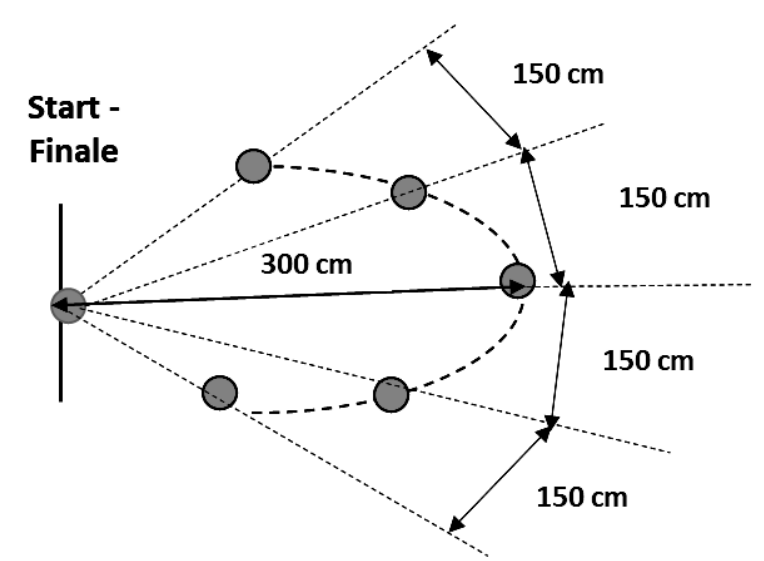

Figure 3. Orientation shuttle run test (OSR) 
Each test includes either the upper limbs or the lower limbs in order to avoid any confusion between the measured motor coordination ability. The first Backwards ball throw test (T1BBT) allows to evaluate the kinesthetic capability of the upper limbs for the finely differentiated management of the dynamic spatial-temporal motor parameters (Figure 1). The second test, a " Low jump test " (T2LJ), is to assess the kinesthetic ability of the lower limbs where the participants are instructed to land their heels on the marked line (Figure 2). The third test -" Orientation shuttle run test " (T3OSR) for assessing the kinesthetic ability of the lower limb response orientation ability (Figure 3).

\section{Statistical analysis}

Analysis of variance (ANOVA) was used to analyse the differences among group means in the samples. ANOVA provides a statistical test of whether the population means of several groups are equal. ANOVA is useful for comparing (testing) three or more group means for statistical significance. Information on the multiple comparisons between each pair of subgroups is provided by Tukey's HSD (honestly significant difference) test. The coefficient eta is also calculated, which makes it possible to estimate the practical magnitude of the differences. It is a coefficient of determination and shows what percentage of the total dispersion of values is explained by belonging to the groups. The Effect Size Variable (Cohen f difference) was also calculated. Limit values for assessing the magnitude of differences in literature indicate - up to 0.02 - small differences, to 0.15 - moderate differences, to 0.35 significant differences and over 0.35 - large differences between groups.

\section{RESULTS}

The results of the screening of the hypothesis of equivalence of the mean values of the demographics benchmark context for the examined 9-10-year-old boys are presented in the ANOVA table (Table 2).

Table 2. One-Way ANOVA table of the variables $(p \leq 0.05)$

\begin{tabular}{llrrlll}
\hline Variables & Source of dispersion & SS & df & MS & F & Sig. \\
Backwards & Between Groups & 19.12 & 4 & 4.78 & 8.78 & .000 \\
ball throw test & Within Groups & 304.26 & 559 & .54 & & \\
& Total & 323.38 & 563 & & & \\
Low jump test & Between Groups & 546.638 & 4 & 136.66 & 8.21 & .000 \\
& Within Groups & 9301.46 & 559 & 16.64 & & \\
& Total & 9848.09 & 563 & & & \\
Orientation & Between Groups & 132.40 & 4 & 33.104 & 19.96 & .000 \\
shuttle run test & Within Groups & 926.98 & 559 & 1.66 & & \\
& Total & 1059.39 & 563 & & & \\
\hline
\end{tabular}

The observed significant dispersion for very large and small cities can be explained by the different opportunities for practicing sport (very large cities) and good natural coordination for sport in the small towns.

The empirical value of Fischer's F- in the different categories of populated place Criterion for the first test - Backwards ball is statistically significant (Figure 4, Table throw test was $F_{e m p}=8.78$ at degrees of freedom df $1=\mathrm{k}-1=4$ and $\mathrm{df} 2=\mathrm{nk}-1=559$ $F_{\text {emp }}>F_{0.05}$, which means that the difference in the demographic motor coordination abilities and Critical Criterion F $0.05 ; 2 ; 21=2.37$. 
3). The same conclusion is imposed by the (3.88 p. SD \pm .59$)$ and Small cities (3.75 p. SD significance level $\mathrm{Sig}=0.000$. We found out, \pm 0.70 ) compared with pupils from Big cities that distance mean values measured in points (3.45 p. SD \pm .88$)$, Medium cities (3.47 p. SD indicated the better level of upper limb kines- \pm .66$)$ and Very small (3.42 p. SD \pm .72$)$. thetic differentiation for pupils from Sofia city

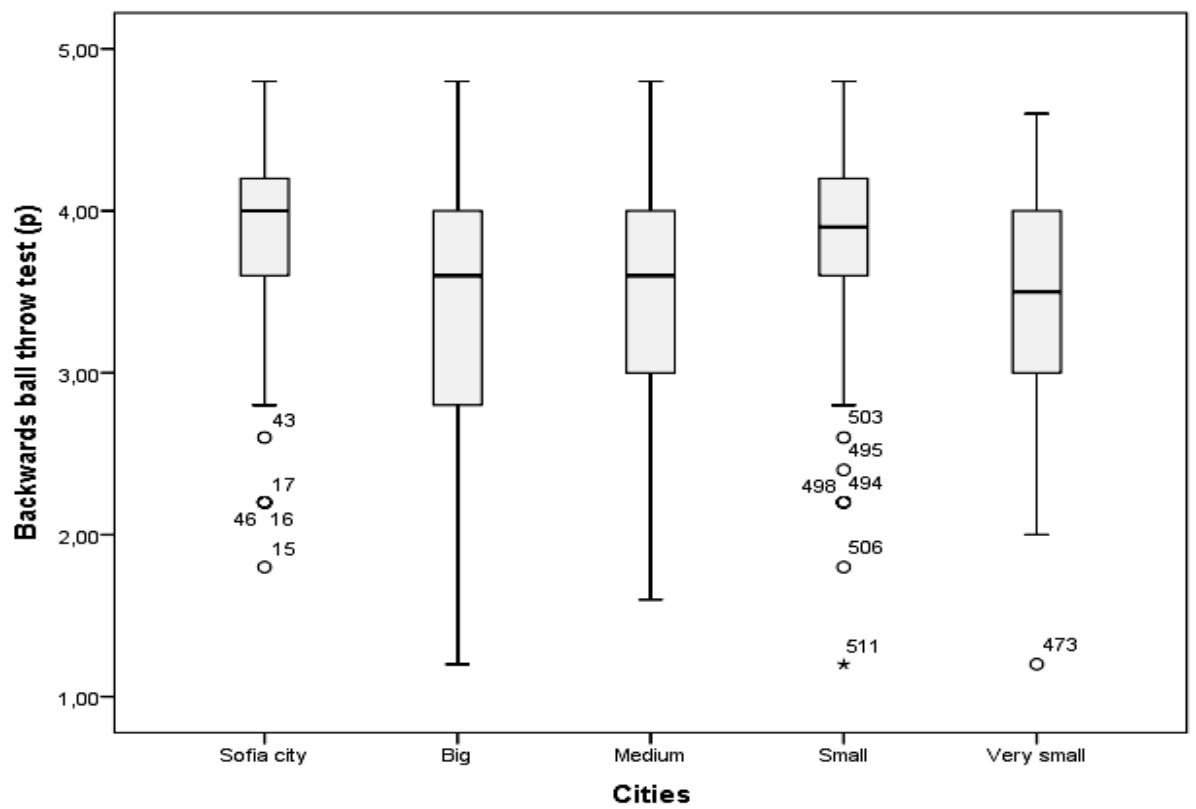

Figure 4. Box-plot diagram of Backwards ball throw test performance comparison $(M=3.59$ point; $\alpha=0.00$ )

For test 2, a Low jump test was $F_{\text {emp }}=$ ties in the different categories of settlements 8.21 at degrees of freedom df $1=\mathrm{k}-1=4$ and is statistically reliable. The same conclusion is df $2=$ nk-1 $=559$ and critical criterion $\mathrm{F}_{0.05} ; \quad$ imposed by the significance level Sig $=0.000$ $F_{\text {emp }}>\mathrm{F}_{0.05}$, which also means that in this test (Figure 5, Table 3). the difference in the motor coordination abili-

Table 3. Descriptive statistics of the variables

\begin{tabular}{ccccc}
\hline \multicolumn{1}{c}{ Variables } & Town codes & $\mathbf{N}$ & Mean & Std. Deviation \\
& 1.00 & 118 & 3.88 & .59 \\
Backwards ball & 2.00 & 189 & 3.45 & .88 \\
throw test & 3.00 & 129 & 3.47 & .66 \\
& 4.00 & 84 & 3.75 & .70 \\
& 5.00 & 44 & 3.42 & .72 \\
& Total & 564 & 3.59 & .76 \\
\hline \multirow{3}{*}{ Low jump test } & 1.00 & 118 & 7.87 & 4.05 \\
& 2.00 & 189 & 7.22 & 4.28 \\
& 3.00 & 129 & 7.20 & 3.19 \\
& 4.00 & 84 & 9.43 & 4.21 \\
& 5.00 & 44 & 10.02 & 5.20 \\
& Total & 564 & 7.90 & 4.18 \\
\hline
\end{tabular}




\begin{tabular}{lcccc} 
& 1.00 & 118 & 11.70 & 1.44 \\
& 2.00 & 189 & 10.52 & 1.24 \\
Orientation & 3.00 & 129 & 10.74 & 1.23 \\
shuttle run test & 4.00 & 84 & 11.34 & 1.38 \\
& 5.00 & 44 & 10.42 & .99 \\
& Total & 564 & 10.93 & 1.37 \\
\hline
\end{tabular}

The mean values of the distance measured in $\mathrm{cm}$ showed a better level of the kinesthetic capability of the lower limbs, with synchronous muscular effort in the horizontal plane for the pupils from the capital $(7.87 \pm 4.05 \mathrm{~cm})$, the big cities $(7.22 \pm 4.28 \mathrm{~cm})$ and the medium cities $(7.20 \pm 3.19 \mathrm{~cm})$, compared to small $(10.02$ $\pm 4.21 \mathrm{~cm})$ and very small cities $(7.90 \pm 5.20$ $\mathrm{cm})$. This can be explained by better teachers' qualifications as well as the additional sports activities led by the specialists at extra-time for the boys from very large, large and medium sized cities.

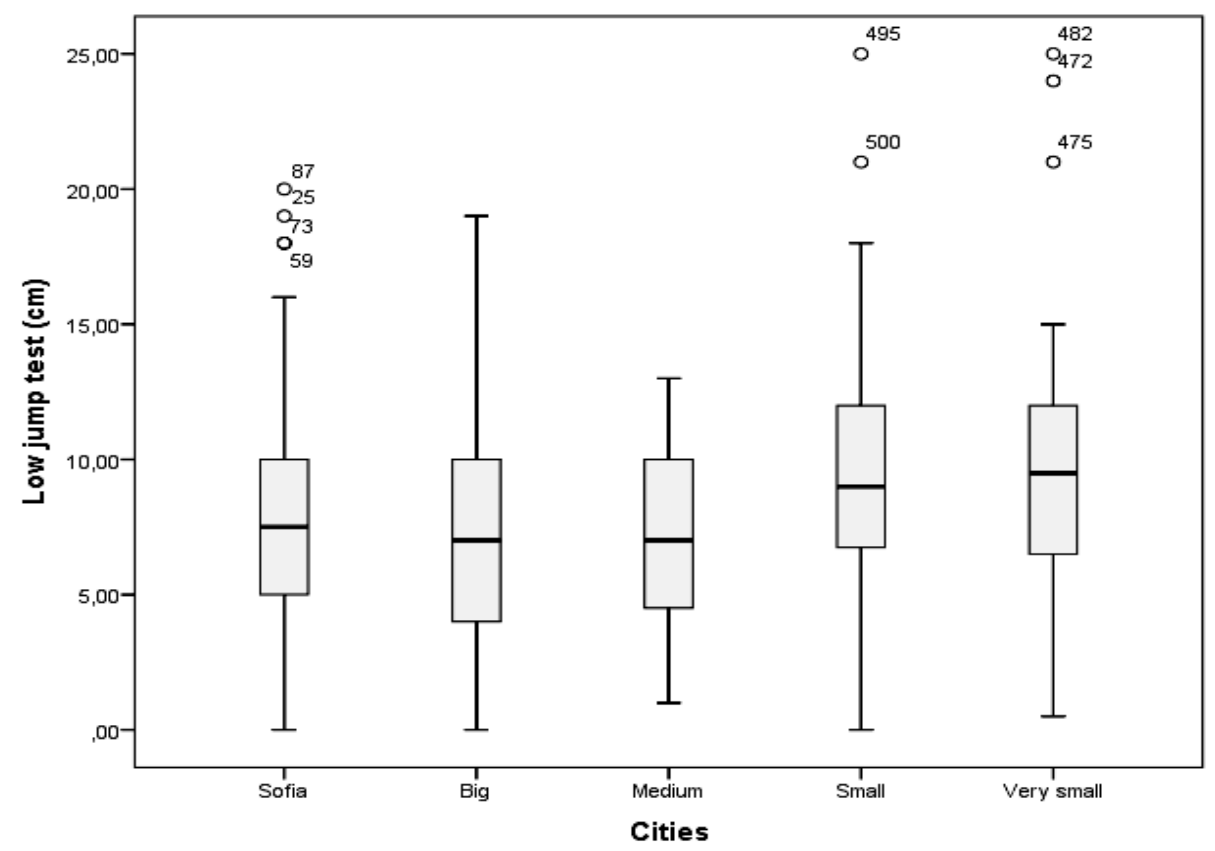

Figure 5. Box-plot diagram of Low jump test performance comparison $(M=7.90 \mathrm{~cm} ; \alpha=0.00)$

For Test 3 - Orientation shuttle run test again, the difference in motor coordination abilities from the demographic benchmark context was statistically significant $-F_{\text {emp }}=$ 19.96 at degrees of freedom df $1=\mathrm{k}-1=4$ and $\mathrm{df} 2=\mathrm{nk}-1=559$ the critical value of criterion $\mathrm{F}$ $0.05 ; 2 ; 21=2.37, F_{\text {emp }}>\mathrm{F}_{0.05}$, and Significance Level Sig. $=0.00$. Analysing the level of spatial orientation abilities in T3OSR, measured in sec, there is a difference in performance in favour of pupils in large cities $(10.52 \pm 1.24$ $\mathrm{s})$, medium $(10.74 \pm 1.23 \mathrm{~s})$ and very small cities $(10.42 \pm 0.99 \mathrm{~s})$ compared to their peers from very large $(11.70 \pm 1.44 \mathrm{~s})$ and small cities $(11.34 \pm 1.38 \mathrm{~s})$. This test provides a comprehensive assessment of kinesthetic abilities, the speed of complex motor response and attention parameters. The strong dissipation of the results concerning large cities is an indicator that there are also pupils who experience serious difficulties in crossing the route and, therefore, possess a low level of coordination skills development. (Table 3, Figure 6). 


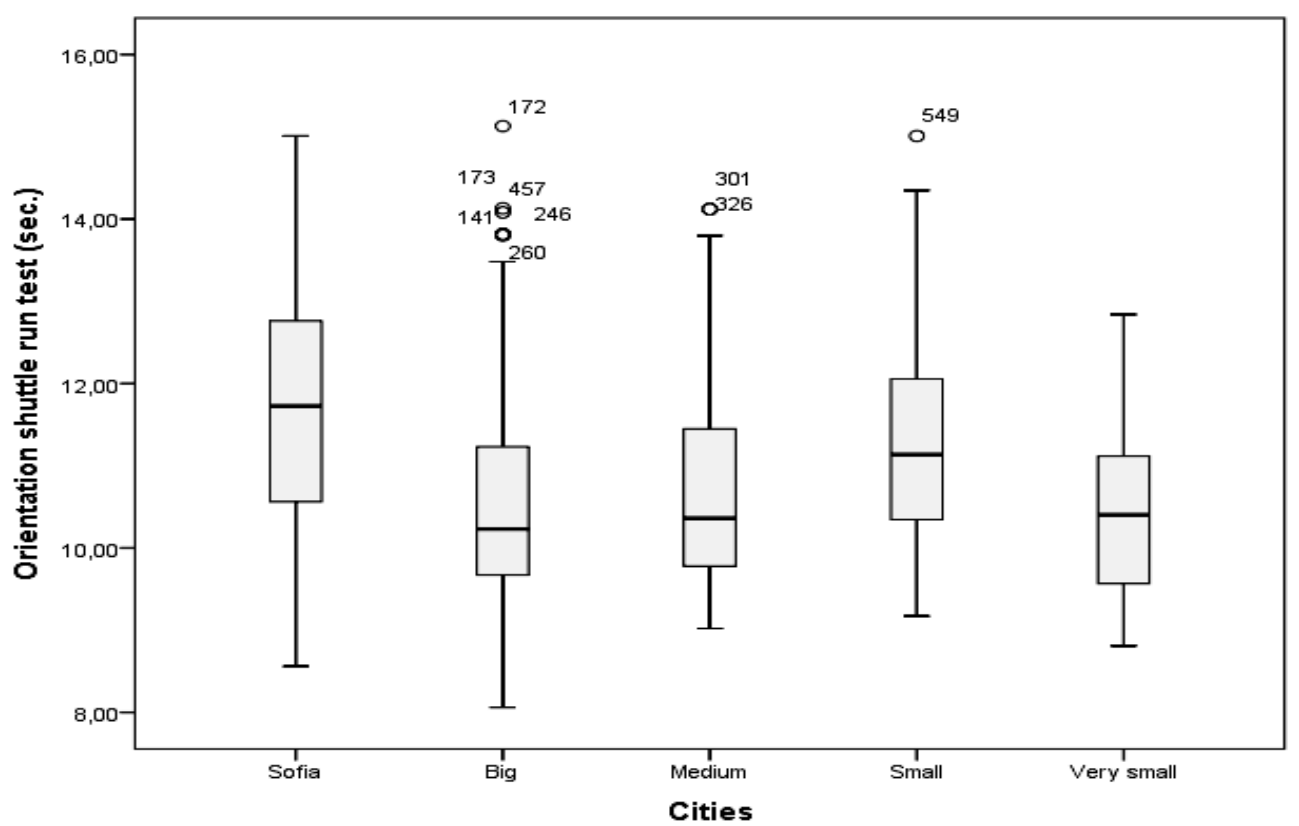

Figure 6. Box-plot diagram of Orientation shuttle run test performance comparison $(M=10.93 \mathrm{~s} ; \alpha=0.00)$

To estimate the practical magnitude of the small or $5.5 \%$ of the variance of the values differences, the coefficient eta $(\eta)$ and $\mathrm{Co}^{-}$is explained by belonging to the group. Cohen's fware used. In our case for Test 1 , which hen's $\mathrm{f}$ value is is $f_{\text {Cohen }}=\frac{0.055}{1-0.055}=0.058$, informs about the level of kinesthetic ability which again speaks of a small practical difof the upper limbs allowing a finely differentiated management of the dynamic spatialtemporal parameters of the movement of the studied 9-10-year-old boys, the difference calculated was 0.05 and means that a small difference or $5.9 \%$ of the variance of the values is explained by belonging to the groups. Cohen's f value $f_{\text {Cohen }}=\frac{0.059}{1-0.059}=0.06$, which indicates also a small practical difference between the compared average values. For Test ference between the comparison averages and this test. In the third test, the kinesthetic ability of the lower limbs the difference was 0.12 and here the difference is moderate or $12 \%$ of the variance of the values is explained by belonging to the groups. Cohen's $f$ value is $f_{\text {cohen }}=\frac{0.12}{1-0.055}=0.14$, which also indicates a moderate practical difference between the averaged values for Test 3 .

The results from the comparisons in pairs 2 - the kinesthetic ability of the lower limbs, are presented in the Multiple Comparisons the difference was 0.05 and again means that table (Table 4).

Table 4. Multiple correlations between the variables (Tukey HSD, $p \leq 0.05$ )

\begin{tabular}{cccccc}
\hline Groups & $\mathbf{1}$ & $\mathbf{2}$ & $\mathbf{3}$ & $\mathbf{4}$ & $\mathbf{5}$ \\
\hline & \multicolumn{5}{c}{ Backwards ball throw test } \\
\cline { 3 - 5 } & & $.43^{*}$ & $.42^{*}$ & & $.46^{*}$ \\
3 & $-.43^{*}$ & & & $-.30^{*}$ & \\
4 & $-.42^{*}$ & & & $-.27^{*}$ & \\
5 & & $.30^{*}$ & $.28^{*}$ & & \\
\hline
\end{tabular}


Low jump test

\begin{tabular}{|c|c|c|c|c|c|}
\hline \\
\hline 1 & & & & & $2.15^{*}$ \\
\hline 2 & & & & $2.21 *$ & $2.80^{*}$ \\
\hline 3 & & & & $2.24 *$ & $2.82^{*}$ \\
\hline 4 & & $2.21 *$ & $2.23^{*}$ & & \\
\hline 5 & $2.15^{*}$ & $2.80^{*}$ & $2.82 *$ & & \\
\hline \multicolumn{6}{|c|}{ Orientation shuttle run test } \\
\hline 1 & & $1.18^{*}$ & $.97 *$ & & $1.27^{*}$ \\
\hline 2 & $-1.18 *$ & & & $-.81 *$ & \\
\hline 3 & $-.97 *$ & & & $-.60 *$ & \\
\hline 4 & & $.81 *$ & $.61 *$ & & $.91 *$ \\
\hline 5 & $-1.27 *$ & & & $-.92 *$ & \\
\hline
\end{tabular}

The statistically significant differences (MD) are marked with a symbol (*).

It can be seen that there was a statistically significant difference in the first test for motor coordination abilities of 9-10-year-old boys between the first group (Sofia city) and the second group (Plovdiv and Burgas) $(M D=$ .43 p.), between the first and the third $(M D=$ .42 p.) and between the first and fifth group (very small towns - Kubrat and Smilyan) $(M D=.46 \mathrm{p}$.) at level of significance $\alpha=0.00$. Such was missing when comparing Sofia city with small towns (Smolyan and Svilengrad) ( $\alpha=$.74) (first - fourth group). There was not a statistically significant difference between the second and third groups (large towns and medium-sized towns) as well as between small and very small towns.

However, there was a statistically significant difference between medium-sized towns and small towns $(M D=.28 \mathrm{p}$.) in favour of the cities with medium population. The result is supported by the necessary statistical significance $-\alpha=0.05$.

It is interesting that for the very small towns and the only village of Smilyan there was only one significant difference and it was mentioned above, namely Sofia city (in favour of Sofia city).

The results from the Low jump test showed statistically significant differences between
Sofia city and very small cities $(M D=2.15$ $\mathrm{cm})$ and big cities and small and very small $(M D=2.21 \mathrm{~cm}$ and $M D=2.80 \mathrm{~cm})$ between the medium and small $(M D=2.24 \mathrm{~cm})$ and very small and medium $(M D=2.82 \mathrm{~cm})$. This test (motor coordination ability) seems to differentiate the pupils in context of city population. The same conclusion can be drawn for the last test - Orientation shuttle run where the following significant differences are observed: - Sofia city and Big cities ( $M D=-1.18 \mathrm{~s})$; Sofia and medium $(M D=-.97 \mathrm{~s})$ and with very small cities $(\mathrm{MD}=-1.27 \mathrm{~s})$ all in favour of Sofia city;

- Big cities and Small one $(M D=0.81 \mathrm{~s})$ in favour of the first;

- Medium and small cities $(M D=0.61 \mathrm{~s})$ also in the favour of the medium;

- Between small and very small $(M D=0.91 \mathrm{~s})$;

- Very small with small $(M D=-0.92 \mathrm{~s})$ in favour of the very small.

Based on the results of the multiple comparisons with the Tukey $\mathrm{B}^{\mathrm{a}, \mathrm{b}}$ for Backwards ball throw test, two subgroups of the tested, represented by their mean values in the Homogeneous Subsets table (Table 5) are formed.

The first subgroup includes representatives of very small cities, big cities and mediumsized cities, whose averages are 3.42 p., 3.45 
p. and 3.47 p. respectively, and the second group - Sofia and small towns whose average values are respectively 3.75 for the first and $3.88 \mathrm{p}$. for the latter. Based on the results of the multiple comparisons with the Tukey $\mathrm{B}^{\mathrm{a}, \mathrm{b}}$ for Low jump test, two subgroups of the examined, presented with their mean values in the Homogeneous Subsets table (Table 6), are also formed. The first subgroup includes the representatives of the middle cities, the big cities and the Sofia city, whose averages are respectively $7.20 \mathrm{~cm}, 7.22 \mathrm{~cm}$ and $7.87 \mathrm{~cm}$, and the second group - the small towns and the very small towns whose average values are respectively $9.43 \mathrm{~cm}$ for the first and $10.02 \mathrm{~cm}$ for the second ones.

For Orientation shuttle run test, two demographic subgroups are presented based on the results of the multiple comparisons with the Tukey $\mathrm{B}^{\mathrm{a}, \mathrm{b}}$, represented by their mean values in the Homogeneous Subsets table (Table 7). The first subgroup includes the representatives of the very small towns by population, the large and medium-sized ones, whose averages are $10.42 \mathrm{~s}, 10.52 \mathrm{~s}$ and $10.74 \mathrm{~s}$ respectively, and the second group - small towns and Sofia city whose average values are respectively $11.34 \mathrm{~s}$ for the first and $11.70 \mathrm{~s}$ for the second ones.

\section{DISCUSSION}

Migration processes in the country have been part of demographic processes in the last years. According to NNC data, the largest movement is in the city-city direction (38 per cent). With lesser scope are the migration processes in the directions "city-village" and "village-town" (http://www.nsi.bg/bg/content/2981/). This affects the socio-economic life of different social fields, such as education and sport.

In the case of physical education and sports, the problems are related to: insufficient sports facilities or lack of them; low qualification of teachers; conducting the physical education classes by the class supervisors; lack of specialists (coaches) for the extra hours, etc. All these facts affect the degree of mastery of the necessary motor skills and habits and the development and manifestation of the basic physical (physical) qualities, incl. the motor coordination abilities of the younger generation.

Moreover, it seemed that the test battery has a high applicability since it turned out to be effective for a wide age range, from kindergarten children (Chang et al., 2013) to adolescents aged 13-16 years of an elite performance school (Budde et al., 2008). Demonstrating its effectiveness, it will be important to promote implementation of coordinative multilateral physical education programmes and to invest in quality physical education programmes as widely as possible (Gallotta, 2014).

Probably, planned and long-term coordinated teaching activities can make children more active, develop the motor skills of 9-10-year-old children, and bring them up to an upper level of education in terms of psychomotor development levels.

Given the increasing movement complexity during growth it is crucial to develop coordination during young school-age. An effective training program for children must take into account the psycho-physical particularities of each age range, in order to focus on and to exploit to the maximum the specific age-related motor learning abilities (Ricotti, 2011).

The comparative analysis of the surveyed indicators will allow to reveal the specificities of the motor coordination abilities of the third grade children by demographic characteristics. On this basis, an experimental methodology for developing these abilities could be elaborated, and a normative system for control of the training process in physical education and sport for Bulgarian schools could be introduced. 


\section{CONCLUSION}

Our results provide clear evidence that there are statistically significant difference depending of the number of town population in manifestation of the motor coordination abilities of 9-10- year-old boys.

The most significant practical difference is observed for Orientation shuttle run test or for kinesthetic ability of the low limbs.

Multiple comparisons show that for the first test - Backwards ball throw test that there are not statistically differences between small cities and Sofia city. Probably the pupils from small cities (Smolyan and Svilengrad) are as talented to perform the coordination exercises

Table 5. Backwards ball throw test as those from Sofia city. For the second test - Low jump test the results show statistically significant differences for almost all compared pairs. The same conclusion is also valid for Orientation shuttle run test. This means that the number of people in the populated area can be a differentiating factor for the manifestation of various motor skills, including motor coordination abilities.

During the coordination training, it is necessary to use the differentiated approach which is based on the strength of pupils' nervous system. Such approach allows to open the reserves of pupils and improve the motor coordination abilities.

\begin{tabular}{|c|c|c|c|}
\hline \multicolumn{4}{|c|}{ Tukey B B $^{\mathrm{a}, \mathrm{b}}$} \\
\hline \multirow[b]{2}{*}{ Population (cities, towns) } & \multirow[b]{2}{*}{$\mathbf{N}$} & \multicolumn{2}{|c|}{$\alpha=0.05$} \\
\hline & & 1 & 2 \\
\hline Very small & 44 & 3.42 & \\
\hline Big cities & 189 & 3.45 & \\
\hline Medium & 129 & 3.47 & \\
\hline Small & 84 & & 3.75 \\
\hline Sofia & 118 & & 3.88 \\
\hline
\end{tabular}

Table 6. Low jump test

Tukey B ${ }^{\mathrm{a}, \mathrm{b}}$

\begin{tabular}{cccc}
\hline & & \multicolumn{2}{c}{$\alpha=0.05$} \\
\cline { 3 - 4 } Population (cities, towns) & $\mathbf{N}$ & $\mathbf{1}$ & $\mathbf{2}$ \\
\hline Medium & 129 & 7.20 & \\
Big cities & 189 & 7.87 & \\
Sofia & 118 & & 9.43 \\
Small & 84 & & 10.02 \\
Very small & 44 & & \\
\hline
\end{tabular}

Table 7. Orientation shuttle run test

Tukey B $^{\mathrm{a}, \mathrm{b}}$

\begin{tabular}{cccc}
\hline & & \multicolumn{2}{c}{$\alpha=0.05$} \\
\cline { 3 - 4 } Population (cities, towns) & $\mathbf{N}$ & 10.42 & $\mathbf{2}$ \\
\hline Very small & 44 & 10.52 & \\
Big cities & 189 & 10.74 & \\
Medium & 129 & & 11.34 \\
Small & 84 & & 11.70 \\
Sofia & 118 & &
\end{tabular}




\section{LIMITATIONS OF THE STUDY}

Because the study is a personal idea, not national or under the project, we take into account the time given us by the school directors - 1 school hour is 40 minutes. On average, in one class, 22-23 students were examined, which allowed us to run a maximum of three tests.

For the upper limbs motor coordination abilities, we used only the Backwards ball throw test, the fourth test - Hanging target throw test we did not apply.

The study was conducted with 564 boys and 509 girls, but in this paper only boys' results were analysed.

The anthropometric indicators as Height (cm), Weight $(\mathrm{kg})$ and BMI $\left(\mathrm{kg} / \mathrm{m}^{2}\right)$ are to be included in the main intervention experiment.

\section{REFERENCES}

Bernstein, N. A. (1991). O lovkosti I ee razviti, Fizkultura i sport, Moskva

Boeva, S. (2012). Efekt na modulnoto obuchenie za razvitieto na fizicheskata godnost na uchenicite ot nachalna uchilishtna vazrast, Sbornik trudove ot IV mejdunarodna nauchna konferenciya, "Kineziologiya" 2012, I\&B 1td, V. Tarnovo, pp. 219-225

Budde, H., Voelcker-Rehage, C., PietrabykKendziorra, S., Ribeiro, P., Tidow, G. (2008). Acute coordinative exercise improves attentional performance in adolescents. Neuroscience Letters, 441(2), 219-223.

Chelyshev, N. N. (2012). Analiz ponyatiy: "Koordinaciya dvizheniy", "Koordinacionnie sposobnosti”, "Lovkost”. Nauchniy poisk, 2.7, Moskva, pp.50-54

Chang, Y. K., Tsai, Y. J., Chen, T. T., Hung, T. M. (2013). The impacts of coordinative exercise on executive function in kindergarten children: an ERP study. Experimental Brain Research, 225(2), 187-196.

Cholakov, N. (2012). Demografskite procesi - isoriya, tendencii I prespektivi, sb. "Nauchni trudove" na UNSS, 2012, No 1, Izdatelski kompleks - UNSS, Sofia, pp. 119

Di Cagno, A., Battaglia, C., Giombini, A.,
Piazza, M., Fiorilli, G., Calcagno, G., Pigozzi, F., Borrione1, P. (2013). Time of Dey - Effects on Motor Coordination and Reactive Strength in Elite Athletes and Untrained Adolescents, Journal of Sports Science § Medicine, Mar; 12 (1), pp. 182-189

Dimitrova, Sv. (1975). Psihologichni problemi na fizicheskoto va zpitanie v uchilishte, Sofia

Fedyakina, L. K. (1998). Razvitie koordinacionih I intellektualnih sposobnostey shkolnikow mladshih klassov na osnove vosrastnih zakonomernostey organizacii dvizheniya. Diss., Sochi

Gallotta, M. C. (2014). Coordination exercise for children health. In: Handbook of Physical Education Research, ISBN: 978-1-63321-076-9, Editor: Ricky Todaro, pp.193-220.

Grosser, M., Starischka, S., Zimmermann, E. (2004). Das neue Konditionstraining für alle Sportarten, für Kinder, Jugendliche und Aktive, Broschiert, BLV, München

Grozdeva, N. (2010). Dvigatelnata koordinaciya za efektivno obuchenie po fizichesko vazpitanie i sport. Nauchni trudove na Rusenskiya uneversitet, 2010, Vol. 49, No 8.2, pp. 174

Hirtz, P. (1985). Koordinative Fähigkeiten im Schulsport, Volk und Wissen Verlag, Berlin

Hirtz, P. (1986). Koordinacionnite sposobnosti v uchilishtnoto fizichesko vazpitanie, Vaprosi na fizicheskata kultura, No 6, Sofia

Hirtz, P., Arndt, K.J., Holtz, D., Jung, R., Ludwig, G., Schielke, E., Wellnitz, I., Willert, K.J., and Vilkner, K.J. (1985). Koordinative Fähigkeiten im Schulsport, Volk and Wissen Verlag, Berlin

Hirtz, P., Hotz, A. \& Ludwig, G. (2000). Gleichgewicht, Karl Hofmann Harausgeber, Schorndorf

Hirtz, P., Starosta. W.(2002). Sensitive and critical periods of motor coordination development and its relation to motor learning, Journal of Human Kinetics, Vol. 7, pp. 19-28.

Ignatov, D. (2017). Senzitivnost na fizicheskoto razvitie, fizicheskata deesposobnost I motorikata na detsata ot nachalna uchilishtna vazrast. LIBRA SKORP, Burgas, ISBN 978619-7123-70-8 
Kohoutek, M. (2005). Koordinační schopnosti u dětí, FTVS UK, Praha, pp. 33-34, ISBN: 80-86317-34- X.

Lyah, V. I. (2003). Ponyatie «koordinacionne sposobnosti» I «lowkost», TPFK, No 8, Moskva, pp. 44-46

Lyah, V. I. (2006). Koordinacionne sposobnosti: diagnostika I razvitie, TBT, Divizion, Moskva

Magomedov, I. M. (1999). Pedagogicheskie osnovi razvitiya koordinacionnih sposobnostey u uchashtihsya nachalnih klassov, Diss., Mahachkala

Momchilova, A. (1996). Razvitie na koordinacionnite sposobnosti na uchenici ot I - IV klas, sp. Pedagogika, No. 3, Sofia

Momchilova, A. (2002). Vliyanie na razlichnite metodi za razvivane na koordinacionnite sposobnosti varhu razvitieto na intelektualnite kachestva na $7-10$ godishnite uchenici., $\mathrm{Li}$ chnost, motivaciya, sport, No. 4

Nacionalen statisticheski institute. (2019). Naselenie po oblasti, obshtini, naselenie mesta I wazrast, http://www.nsi.bg/bg/content/2975/,accessed 27 February 2019

Pisarenkova, E. P. (2010). Razvitie specificheskih koordinacionnih sposobnostey u shkolnikov 7-15 let raznih tipov konstitucii. Avtoreferat, Tula

Raczek, J., Mynarski, W., Ljach, W. (2003). Ksztattowanie i diagnozowanie koordynacyjnych zdolnosci motorycznych, APE Publ., Katowice, pp. 237

Ricotti, L. (2011). Static and dynamic balance in young athletes. Journal of Human Sport and Exercise, 1988-5202, vol 6, N 4, 616-
6286 (4), pp. 616-628. https://doi.org/10.4100/ jhse.2011.64.05

Roth, K. (2014). Zur Sache: Koordinative Fähigkeiten. Grundschule Sport, 1, (1), Hofmann, Schorndorf, pp. 7.

Rusev, R. (1995). Kibernetichen model na koordinacionnite sposobnosti. Sport I nauka, No 9, Sofia.

Rusev, R. (2005). Strukturno-funkcionalni modeli na dvigatelnata koordinaciya v sportnata deynost. Diss., Sofia

Sugareva, M. (2017). Demografiyata kato nauka I osobenosti na demografskoto razvitie na Balgariya. Izdanie za obrazovanie, nauka I kultura, Plovdivski uneversitet. Br. 1-2 (466-467), godina XXXV, 24.02.2017, pp. 2

Turchak, N. L. (2014), Razvitie koordinacionnih sposobnostey u detey mladshego shkolnogo vozrasta na urokah fizkultura, Kazahstan

Uchebna programa po fizichesko vazpitanie I sport za III klas (obshtoobrazovatelna podgotovka)v sila ot uchebnata 2018-2019 godina, utvardena sas Zapoved № РД09-1093/25.01.2017, https://www.mon.bg/bg/1689, accessed 5 February 2019

Zamashkin K. S., Tolstova S. Y. (2013). Razvitie na koordinacionnih sposobnostey u detey mladshego shkolnogo vozrosta. Uspehi sovremennogo estestvoznaniya, No 10, Moskva, pp. 28-29

Zlatev, B., Bachev, V., Groshev, O., Yordanov, P. (2016). Tehnologichen transfer na optikoelektrichni metodiki - metrologichen primer pri testovete za izmervane na lovkost. Metrologiya I metrologichno osiguryavane - dokladi, TU, Sofia, pp. 221-227

\section{Corresponding author:}

Nikolina Tankoucheva

Department of Primary School Pedagogy Faculty of Educational Studies and the Arts

Shipchenski prohod 69 A Sofia 1574, Bulgaria E-mail: ninagym1@gmail.com 